\title{
12. Sociologist-Spy in the Atomic Archive
}

\author{
Lindsey A. Freeman
}

Lindsey A. Freeman is a writer and sociologist. She is author of This Atom Bomb in Me (Redwood/Stanford Press, 2019) and Longing for the Bomb: Oak Ridge and Atomic Nostalgia (University of North Carolina Press, 2015). Originally from atomic Appalachia, Freeman teaches on top of a sci-fi mountain in Canada in the Sociology \& Anthropology Department at Simon Fraser University, Vancouver British Columbia.

lindsey freeman@sfu.ca

In this research, I employ the popular Benjaminian tool of "brushing history against the grain."1 My sensibilities and sociological training demand this effort, although, my relationship to Oak Ridge, Tennessee, the "Atomic City," at times makes this practice uncomfortable. The folks I have spoken to during my fieldwork, who have been so kind and generous, have given me coffee and cookies and told me stories, will not universally agree with what I have written about their city. It might cause some sore feelings and tense conversations. I am prepared for the splinters I will incur from brushing this history against its grain, hoping that Adorno is right that "the splinter in your eye is the best magnifying glass."2

This is the burden of the sociologist, the burden of the outsider who studies a place. In the opening pages of Let Us Now Praise Famous Men, James Agee goes so far as to call himself a "spy." The spy metaphor pops up again in Peter Berger's Invitation to Sociology. My relationship to Oak Ridge has sometimes felt this way. My insider-outsider status (I was born in Oak Ridge, my mother grew up there and my grandparents lived there since 1943 and the secret city days of the Manhattan Project) has occasionally made me feel like a double agent, 
critical and understanding by turns, as I have tried to make sense of this place as it confronts its atomic past and nuclear legacy. I feel this most when I'm in the archives.

In following Walter Benjamin, I have tried to develop a kind of "mental atomic fission" and a way of looking at multiple time periods simultaneously, where patterns of social practices and social outlooks could be observed. ${ }^{3}$ This is not possible without access to large amounts of documents. By spreading out files, I have found in the secret city of Oak Ridge what Italo Calvino found in his Invisible Cities: "The city is redundant: it repeats itself so that something will stick in the mind" and also that "memory is redundant: it repeats signs so that the city can begin to exist." ${ }^{4}$ From the archive to my grandfather and grandmother - to my mother and uncle, to me - some of the stories of the Atomic City repeat. As Walter Benjamin writes in "The Storyteller": "Memory creates the chain of tradition which passes a happening on from generation to generation." Although each new storyteller tells the story of the happening a bit differently, "traces of the storyteller cling to the story the way the handprints of the potter cling to the clay vessel." 5

In my years of studying Oak Ridge, I have visited touristic sites such as museums and monuments, but I've also visited moth-balled nuclear factories; I've been chased by squatters out of the aging Oak Ridge Guest House, now known as the Alexander Inn, which housed traveling dignitaries and star atom splitters during the Manhattan Project; I've tramped through the woods getting brambles stuck to my jeans to get a look at ruins of the former trailer park community, where the Manhattan Project construction workers were housed; and I've also done less dramatic things, like going to the archives and drinking coffee with my grandmother 
in her Manhattan Project era house, while she told me stories. This research attempts to understand and articulate not only one small city's connection with the Bomb, but also to provide a piece of a larger story that remains to be written: the story of the American relationship to the decline of the Atomic Age.

${ }^{1}$ Walter Benjamin, "On the Concept of History," in Selected Writings, vol. 4, 1938 1940, p. 391. Cambridge, MA: Belknap Press of Harvard University Press, 2003.

2 Theodor Adorno, Minima Moralia, p. 50 New York: Verso, 1974.

3 Theodor Adorno described his friend Benjamin's intellectual abilities as "mental atomic fission" in "A Portrait of Walter Benjamin," p. 230 in Prisms. Cambridge, MA: MIT Press, 1967.

${ }^{4}$ Italo Calvino, Invisible Cities, 19.

${ }^{5}$ Walter Benjamin, "The Storyteller," in Illuminations, pp. 98, 92. New York: Schocken Books, 1968. 